\title{
A Combination of Phenotypic and Genotypic Characterization Strengthens Pyrenophora tritici-repentis Race Identification
}

\author{
Rachael M. Andrie, Iovanna Pandelova, and Lynda M. Ciuffetti
}

Department of Botany and Plant Pathology, Oregon State University, Corvallis 97331.

Current address of R. M. Andrie: Division of Infectious Diseases, Department of Medicine, Oregon Health and Science University, Portland 97239.

Accepted for publication 19 December 2006.

\section{ABSTRACT}

Andrie, R. M., Pandelova, I., and Ciuffetti, L. M. 2007. A combination of phenotypic and genotypic characterization strengthens Pyrenophora tritici-repentis race identification. Phytopathology 97:694-701.

Pyrenophora tritici-repentis, causal agent of tan spot of wheat, produces multiple host-selective toxins (HSTs), including Ptr ToxA, Ptr ToxB, and Ptr ToxC. The specific complement of HSTs produced by a particular isolate determines its host cultivar specificity. Each unique specificity profile, represented by the differential induction of necrosis or chlorosis on a standard set of wheat differentials, defines a unique race. Eight races of $P$. tritici-repentis have been formally published, although additional races are under investigation. Although visual assessment of disease phenotype is often used in race designation of $P$. tritici-repentis, our results suggest that it has the potential to be misleading. Inoculation of the P. tritici-repentis isolates SO3 and PT82 on the current wheat differential set indicated classification as race 2 and race 8 , respectively; however, genetic characterization revealed that these isolates do not possess the associated HSTs expected for these race assignments. Despite sharing disease phenotypes similar to known races, SO3 and PT82 were genotypically distinct from these previously characterized races of $P$. tritici-repentis. To ensure detection of the breadth of physiological variation among the isolates of $P$. tritici-repentis, our results indicate that race classification, where possible, should include both phenotypic and genotypic analyses and eventual expansion of the differential set.

Additional keywords: host-specific toxins, ToxA, ToxB.
Pyrenophora tritici-repentis, causal agent of tan spot of wheat, is an economically important pathogen of wheat worldwide $(17,20)$. Methods used to categorize isolates of $P$. tritici-repentis have evolved along with our emerging understanding of the complexity of the interaction between $P$. tritici-repentis and wheat. Prior to the identification of the toxic components produced by $P$. tritici-repentis, Lamari and Bernier (34) developed an isolate categorization system based on a series of lesion types. Resistance was characterized by small, noncoalescing dark brown to black spots, with or without slight amounts of chlorosis or tan necrosis. Moderate resistance to moderate susceptibility was characterized by noncoalescing small dark brown to black spots completely surrounded by a distinct chlorotic or tan necrotic ring. Susceptibility was characterized by chlorotic or tan necrotic lesions, the majority of which coalesce.

Furthermore, isolates were categorized into four pathotypes based on whether they produce necrotic or chlorotic symptoms on distinct wheat cultivars (35). Pathotype 1 isolates produce both necrosis and chlorosis; isolates of pathotype 2 and 3 produce only one symptom each, necrosis or chlorosis, respectively; and nonpathogenic pathotype 4 isolates do not produce either symptom. Of the wheat differentials used to create the pathotype system, cv. Glenlea and the line 6B365 are now used consistently for the detection of necrosis and chlorosis, respectively, when assigning a race designation to a particular isolate (20). It now is known that necrosis on Glenlea can be attributed to production of Ptr ToxA (synonyms: Ptr necrosis toxin, Ptr toxin, ToxA) $(9,15,56,57,62)$, a 13.2-kDa (57) proteinaceous host-selective toxin (HST) encoded

Corresponding author: L. M. Ciuffetti;

E-mail address: ciuffetL@science.oregonstate.edu

doi:10.1094/PHYTO-97-6-0694

(C) 2007 The American Phytopathological Society by the ToxA gene $(10,18)$. Additionally, Ptr ToxA is responsible for typical necrotic lesions, which often are surrounded by chlorotic halos, associated with tan spot of wheat. Chlorosis on 6B365 can be attributed to production of Ptr ToxC (21), which appears to be a nonionic, polar, low molecular weight HST, the gene(s) for which has yet to be characterized.

The discovery of a distinct chlorotic symptom on wheat cv. Katepwa caused by a previously uncharacterized isolate of $P$. tritici-repentis led to renovation of the pathotype system (37). Lamari and colleagues (37) proposed a race designation system modeled after that of cereal rusts to describe the isolates of $P$. tritici-repentis. The new race-based system is limited only by the size and effectiveness of the differential set, in contrast to the original pathotype classification system that allowed the description of only four pathotypes. The four pathotypes previously described became races 1 through 4 , and the new isolate was designated as race 5. Additionally, the wheat line 6B662, formerly considered resistant to $P$. tritici-repentis, was introduced as the differential for race 5. Chlorosis on Katepwa and 6B662 is now known to be due to the production of Ptr ToxB (synonym: Ptr chlorosis toxin) (15), a $6.6-\mathrm{kDa}$ proteinaceous HST $(47,52,53)$ encoded by the ToxB gene $(43,44)$. Distinct ToxB-like sequences have been identified in isolates of race $3(50,51)$ and race 4 $(43,51)$, although neither race produces $\operatorname{Ptr} \operatorname{ToxB}(16,51)$ or is pathogenic on Ptr ToxB-sensitive wheat $(34,37)$. In race 3 , all but the first six nucleotides of the ToxB-like sequence are identical to ToxB (50,51); whereas, for race 4, the sequences are more divergent $(43,50)$. For example, the ToxB-like sequence from the race 4 isolate SD20, designated toxb, shares $86 \%$ identity with wild-type ToxB (43).

The virulence patterns of the various races of $P$. tritici-repentis have since been discovered to be toxin-based, in that each compatible interaction between an isolate and its corresponding susceptible host cultivar is mediated by an HST (51). Therefore, 
the specific complement of HSTs produced by a particular isolate determines its race. Ptr ToxA causes necrosis on Glenlea and Katepwa $(9,56,57,62)$, Ptr ToxB causes chlorosis on 6 B662 and Katepwa $(47,52,53)$, and Ptr ToxC causes chlorosis on 6B365 (21). Wheat cvs. Salamouni $(20,51)$ and Auburn $(18,55-57)$ are insensitive to all of the characterized HSTs of $P$. tritici-repentis. Isolates producing all possible combinations of Ptr ToxA, Ptr ToxB, and Ptr ToxC have been identified and accordingly are categorized as races 1 to $8(37,39,51,54)$. The race structure of $P$. tritici-repentis on the commonly used wheat differential set (34, 37,51 ) is summarized in Table 1 , which indicates the toxin production profiles of each race. Both high- and low-virulence race 5 isolates, as indicated by variable levels of chlorotic symptom development on the Ptr ToxB-sensitive wheat line 6B662, have been identified (54).

Although visual assessment of disease phenotype often is used in race designation of $P$. tritici-repentis, our results suggest that it has the potential to be misleading. Specifically, here we report two examples in which genetic characterization differed from phenotypically determined race designations. Although $P$. triticirepentis isolate SO3 is known to lack ToxA (18), it unexpectedly produced a Ptr ToxA-associated disease phenotype. Additionally, disease phenotype alone led us to mistakenly classify an isolate from Kansas (designated PT82) as race 8 (7), which is indicated by the production of the three characterized HSTs, Ptr ToxA, Ptr ToxB, and Ptr ToxC, although genotypic analysis revealed that it does not possess all of the associated HSTs expected for this race assignment. In documenting these examples, our objective was to demonstrate that accurate race classification based on the current set of published differentials should, where possible, include both phenotypic and genotypic characterization in order to reflect the intimate association between race identity and HST production.

\section{MATERIALS AND METHODS}

Fungal isolates. The following two $P$. tritici-repentis isolates were chosen for race characterization: PT82, collected from a field in Kansas, and SO3, collected from a field in southern Oregon (M. L. Putnam and L. M. Ciuffetti, unpublished data).
SO3 originally was designated EO3 and shown to lack the ToxA gene via Southern blot analysis (18). However, at the time, inoculation data for all of the differentials were not generated. For comparison, the following $P$. tritici-repentis isolates served as representatives of races 1 through 5: for race 1, isolate SD8; for race 2 , isolate $86-124(35,37)$; for race 3 , isolate D308 $(35,37)$; for race 4, isolate SD20 (43); and, for race 5, isolate DW7 (4). Ideally, isolates of races 6 (54), 7, and 8 (39) also would have been used for comparison; however, because we were unable to obtain these isolates, information presented here on these races is based on published data.

Culture conditions. Cultures of $P$. tritici-repentis were grown on V8 juice agar $\left(20 \% \mathrm{vol} / \mathrm{vol} \mathrm{V} 8\right.$ juice, $0.3 \% \mathrm{wt} / \mathrm{vol} \mathrm{CaCO}_{3}$, and $2 \% \mathrm{wt} / \mathrm{vol}$ Bacto agar) in constant darkness at $25^{\circ} \mathrm{C}$. Sporulation of $P$. tritici-repentis was induced by flooding a culture with sterile water and manually depressing aerial hyphae with a glass rod, followed by incubations in 18 to $24 \mathrm{~h}$ of light at room temperature and 18 to $24 \mathrm{~h}$ of darkness at $16^{\circ} \mathrm{C}$ (34). To obtain mycelia for DNA extraction, $P$. tritici-repentis conidia were collected in an aqueous solution of $0.015 \%$ Tween 20 , inoculated into $75 \mathrm{ml}$ of quarter-strength potato dextrose broth (BD Difco, Sparks, MD), and grown at room temperature in a rotary shaker at $175 \mathrm{rpm}$ for $16 \mathrm{~h}$. Mycelia were collected and lyophilized. To obtain crude culture filtrates $(\mathrm{CCF})$ for protein precipitations and toxin identification, three no. 3 borer plugs of V8 agar-grown mycelia were inoculated into $50 \mathrm{ml}$ of modified Fries medium (55), followed by incubation as stationary cultures at $25^{\circ} \mathrm{C}$ under constant fluorescent light for 19 days.

Plant material and inoculations. The standard wheat differentials included cvs. Glenlea (34), Katepwa (37), and Auburn $(18,55,56)$ and lines 6B662 (37) and 6B365 (34). Plants were grown for 2 to 3 weeks under diurnal conditions of light for $16 \mathrm{~h}$ at $23^{\circ} \mathrm{C}$ and darkness for $8 \mathrm{~h}$ at $19^{\circ} \mathrm{C}$ prior to inoculation. Wheat seedlings were inoculated with a conidial suspension from each isolate $\left(3 \times 10^{3}\right.$ conidia/ml $)$ to drip stage, incubated overnight in darkness in a dew chamber at $\approx 20$ to $22^{\circ} \mathrm{C}$, then returned to diurnal conditions. Disease development was monitored and secondary leaves were harvested 5 to 8 days post inoculation to document infection phenotype. Inoculations were repeated with

TABLE 1. Race structure of Pyrenophora tritici-repentis ${ }^{\mathrm{a}}$

\begin{tabular}{lllllc}
\hline & & \multicolumn{2}{c}{ Wheat differentials $^{\mathrm{b}}$} \\
\cline { 2 - 6 } Race & Glenlea & \multicolumn{1}{c}{ Katepwa } & 6 B662 & 6B365 & Salamouni \\
\hline 1 & $\mathrm{~N}$ (ToxA) & $\mathrm{N}$ (ToxA) & $\mathrm{R}$ & $\mathrm{C}$ (ToxC) & $\mathrm{R}$ \\
2 & $\mathrm{~N}$ (ToxA) & $\mathrm{N}$ (ToxA) & $\mathrm{R}$ & $\mathrm{R}$ & $\mathrm{R}$ \\
3 & $\mathrm{R}$ & $\mathrm{R}^{\mathrm{c}}$ & $\mathrm{R}^{\mathrm{c}}$ & $\mathrm{C}$ (ToxC) & $\mathrm{R}$ \\
4 & $\mathrm{R}$ & $\mathrm{R}^{\mathrm{c}}$ & $\mathrm{R}^{\mathrm{c}}$ & $\mathrm{R}$ & $\mathrm{R}$ \\
5 & $\mathrm{R}$ & $\mathrm{C}$ (ToxB) & $\mathrm{C}$ (ToxB) & $\mathrm{R}$ \\
6 & $\mathrm{R}$ & $\mathrm{C}$ (ToxB) & $\mathrm{R}$ (ToxB) & $\mathrm{R}$ \\
7 & $\mathrm{~N}$ (ToxA) & $\mathrm{N}$ (ToxA) C (ToxB) & $\mathrm{C}$ (ToxB) & $\mathrm{R}$ & $\mathrm{R}$ \\
8 & $\mathrm{~N}$ (ToxA) & $\mathrm{N}$ (ToxA) C (ToxB) & $\mathrm{C}$ (ToxB) & $\mathrm{R}$ & $\mathrm{R}$ \\
\hline
\end{tabular}

${ }^{a}$ Based on references 37,39 , and 54 .

${ }^{\mathrm{b}} \mathrm{N}=$ necrosis, $\mathrm{C}=$ chlorosis, $\mathrm{R}=$ resistance, ToxA = presence of ToxA and production of Ptr ToxA, ToxB = presence of ToxB and production of Ptr ToxB, ToxC = production of $\operatorname{Ptr} \operatorname{Tox} C$ as evidenced by inoculation, and $\mathrm{NT}=$ isolates of race 6, 7, and 8 were not available for inoculation.

c Although race $3(50)$ and race $4(43,50)$ possess distinct ToxB-like sequences, neither race produces Ptr ToxB $(16,50)$ or is pathogenic on Ptr ToxB-sensitive wheat $(34,37)$.

TABLE 2. Multiplex polymerase chain reaction primers

\begin{tabular}{|c|c|c|c|}
\hline Locus & Primer & Sequence & Source \\
\hline \multirow[t]{2}{*}{ ToxA } & TA51F & 5'-GCGTTCTATCCTCGTACTTC-3' & This study \\
\hline & TA52R & 5'-GCATTCTCCAATTTTCACG-3' & This study \\
\hline \multirow[t]{2}{*}{ ToxB } & TB71F & 5'-GCTACTTGCTGTGGCTATC-3' & This study \\
\hline & TB60R & 5'-ACTAACAACGTCCTCCACTTTG-3' & 43 \\
\hline toxb & TB58R & 5'-TATGAATGATTGACTGGGGTTA-3' & 43 \\
\hline \multirow[t]{2}{*}{ CHS-1 } & CHS-79F & 5'-TGGGGCAAGGATGCTTGGAAGAAG-3' & 11 \\
\hline & CHS-354R & 5'-TGGAAGAACCATCTGTGAGAGTTG-3' & 11 \\
\hline
\end{tabular}


similar results at least four times for SO3 and PT82, and at least two times for races 1 to 5 .

Southern analyses. DNA was purified by the procedure of Martinez and colleagues (43) via organic extraction in conjuncttion with a modified polysaccharide precipitation method (46). DNA concentrations were determined by comparison with $\lambda$ DNA standards on an ethidium bromide-stained $1 \%$ agarose gel. Approximately $1 \mu \mathrm{g}$ of restriction enzyme-digested genomic DNA was size fractionated followed by downward transfer onto ZetaProbe Blotting Membranes (Bio-Rad Laboratories, Hercules, CA) via alkaline transfer. For ToxA-probed Southern blots, DNA was digested with either SacI or EcoRV; for ToxB-probed Southern blots, DNA was digested with either HindIII or EcoRV. Blots were dried at $80^{\circ} \mathrm{C}$ for $2 \mathrm{~h}$, prehybridized in $7 \%$ sodium dodecyl sulfate (SDS), 0.5 $\mathrm{M} \mathrm{NaHPO}_{4}$ (pH 7.2) (a $1 \mathrm{M} \mathrm{NaHPO}_{4}$ [pH 7.2] stock solution is composed of $71 \mathrm{~g}$ of $\mathrm{Na}_{2} \mathrm{HPO}_{4}$ and $4 \mathrm{ml}$ of $85 \%$ $\mathrm{H}_{3} \mathrm{PO}_{4}$ per liter), $0.001 \mathrm{M}$ EDTA ( $\mathrm{pH} 8.0$ ), $1 \%$ bovine serum albumin (BSA) fraction $\mathrm{V}(14)$ at $60^{\circ} \mathrm{C}$ for at least $2 \mathrm{~h}$, and hybridized with labeled probe at $60^{\circ} \mathrm{C}$ overnight.

Membranes were probed with either a 591-bp fragment of ToxA or a 243-bp fragment of ToxB obtained with polymerase chain reaction (PCR). Primers TA4bF (5'-GGTCATGCGTTCTATCCT-

A
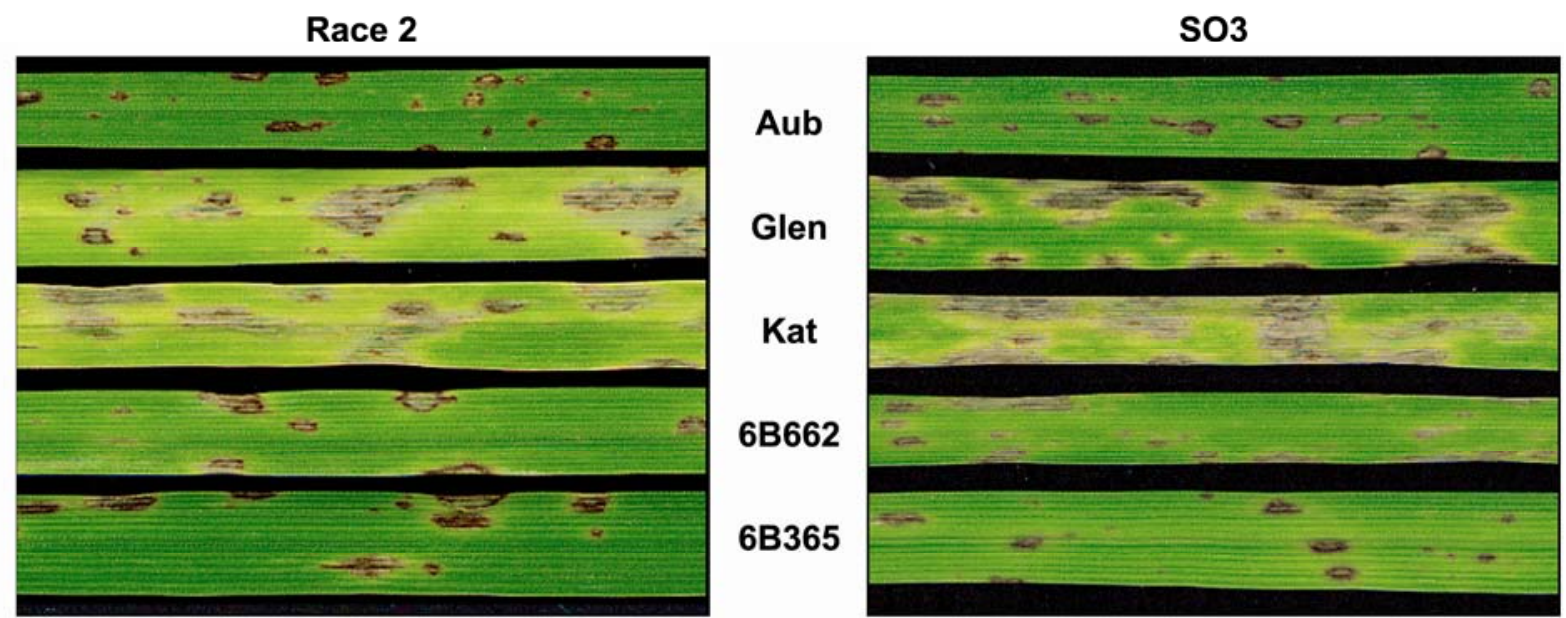

B
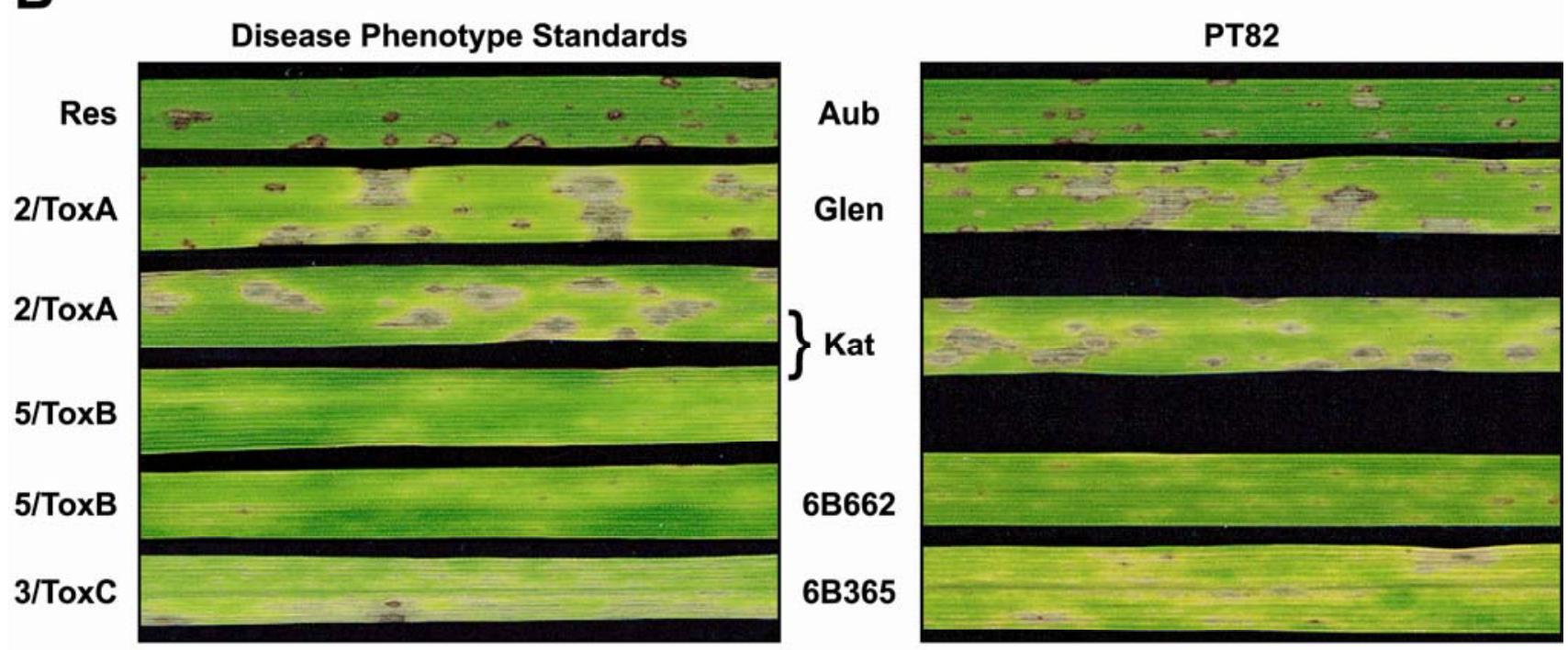

C

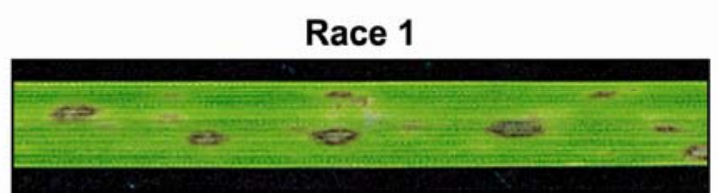

$6 B 662$

Fig. 1. Race designation of Pyrenophora tritici-repentis isolates SO3 and PT82 based on phenotypic characterization. A, Disease reaction of SO3 on the current set of wheat differentials matches that of race 2 (i.e., Ptr ToxA-induced necrosis on the wheat cvs. Glenlea and Katepwa). B, PT82 produces a race 8 disease profile (i.e., Ptr ToxA-induced necrosis on Glenlea and Katepwa, Ptr ToxB-induced chlorosis on Katepwa and 6B662, and Ptr ToxC-induced chlorosis on 6B365) on the current wheat differential set as determined by comparison with disease phenotype standards. Disease phenotype standards represent the disease reaction caused by the production of individual HSTs on corresponding sensitive differentials. These were obtained via inoculation of races that, thus far, have been shown to produce only one toxin each, Ptr ToxA (race 2), Ptr ToxB (race 5), or Ptr ToxC (race 3). Resultant disease phenotypes on corresponding sensitive differentials are assumed to be due to each respective toxin. C, Comparison of PT82 and race 1 on the Ptr ToxB-sensitive wheat line 6B662. Res $=$ resistant, 2/ToxA $=$ Race 2/Ptr ToxA, 5/ToxB = Race 5/Ptr ToxB, 3/ToxC = Race 3/Ptr ToxC, Aub = Auburn, Glen = Glenlea, and Kat = Katepwa. 
CGTAC-3') and TA14bR (58) were used to amplify the ToxA probe. The ToxB probe was amplified by primers TB57F $\left(5^{\prime}-\right.$ GAGACTGCTATGCTACTTGCTG-3') and TB6R (Table 2) (43, 44). The reaction mixture was composed of $1 \times \mathrm{Taq}$ polymerase buffer $(50 \mathrm{mM} \mathrm{KCl}, 1.5 \mathrm{mM} \mathrm{MgCl}, 10 \mathrm{mM}$ Tris. $\mathrm{HCl}, \mathrm{pH} 9.0)$, $200 \mu \mathrm{M}$ each dNTP, $200 \mathrm{nM}$ each primer, $2.5 \mathrm{U}$ of Taq polymerase (MBI Fermentas, Hanover, MD), and $10 \mathrm{ng}$ of template DNA in $50 \mu \mathrm{l}$. Amplification was carried out as follows: 1 cycle of $94^{\circ} \mathrm{C}$ for $3 \mathrm{~min} ; 30$ cycles of $94^{\circ} \mathrm{C}$ for $30 \mathrm{~s}, 58^{\circ} \mathrm{C}$ for $30 \mathrm{~s}$, and $72^{\circ} \mathrm{C}$ for $30 \mathrm{~s}$; and 1 cycle of $72^{\circ} \mathrm{C}$ for $7 \mathrm{~min}$. PCR products were purified on MinElute Spin Columns (Qiagen, Valencia, CA) and $\alpha-$ ${ }^{32} \mathrm{P}$-dCTP-labeled with the Random Primers DNA Labeling System (Invitrogen, Carlsbad, CA) per the manufacturer's instructions.

Hybridization was followed by three washes with $2 \times$ SSC (1× $\mathrm{SSC}$ is $0.15 \mathrm{M} \mathrm{NaCl}$ plus $0.015 \mathrm{M}$ sodium citrate), $0.5 \% \mathrm{SDS}$ at $60^{\circ} \mathrm{C}$ for 5,10 , and $30 \mathrm{~min}$, and a final high stringency wash with $0.2 \times \mathrm{SSC}$ and $2 \% \mathrm{SDS}$ at $60^{\circ} \mathrm{C}$ for $45 \mathrm{~min}$. To detect probe hybridization, blots were exposed to autoradiographic film (Denville Scientific, Metuchen, NJ). At least two independent DNA samples for each isolate were analyzed via Southern analysis.

Western analyses. For Western analyses of Ptr ToxA and Ptr ToxB, total proteins were precipitated from 500- $\mu$ l and $1-\mathrm{ml}$ aliquots of CCF, respectively, via the trichloroacetic acid (TCA) procedure of Ciuffetti and colleagues (18). Protein samples were separated by $12 \%$ SDS polyacrylamide gel electrophoresis (SDSPAGE) in the buffer system of Fling and Gregerson (23). SDSPAGE gels then were equilibrated in transfer buffer $(25 \mathrm{mM}$ Tris Base, $193 \mathrm{mM}$ glycine, 20\% methanol), followed by dry transfer of proteins to GE Pure Nitrocellulose Transfer Membrane (GE Osmonics, Minnetonka, MN). Resultant blots were blocked overnight at $4^{\circ} \mathrm{C}$ in $1 \times$ TBST $(150 \mathrm{mM} \mathrm{NaCl}, 0.05 \%$ Tween 20 , $10 \mathrm{mM}$ Tris- $\mathrm{HCl}, \mathrm{pH} 8.0)$ and $3 \%$ nonfat dried milk. Blots then were washed in $1 \times$ TBST and incubated for $1 \mathrm{~h}$ in either anti-Ptr ToxA N+C fusion protein antisera (41) or anti-Ptr ToxB antisera diluted $1: 10,000$ or $1: 2,000$, respectively, in $1 \times$ TBST and $1 \%$ BSA fraction V. Blots were washed again and incubated for 30 min in anti-rabbit horseradish peroxidase-conjugated secondary antibody (Sigma-Aldrich, St. Louis) diluted 1:8,000 in 1× TBST. Following a final wash, blots were developed via chemilumenescence with SuperSignal West Dura Extended Duration Substrate (Pierce, Rockford, IL) per the manufacturer's instructions. Western analyses were repeated on two independent CCF samples for both Ptr ToxA and Ptr ToxB.

Multiplex PCR. A modification of the FastDNA Kit (Qbiogene, Carlsbad, CA) manufacturer's instructions was used to extract genomic DNA. From 5 to $50 \mathrm{mg}$ of lyophilized fungal tissue was added to lysis matrix A and homogenized for $10 \mathrm{~s}$ at a setting of 4.5 with a FastPrep Instrument (Qbiogene). Immediately following homogenization, $1 \mathrm{ml}$ of CLS-VF cell lysis solution and $200 \mu \mathrm{l}$ of protein precipitation solution (PPS) were added to each sample, followed by a 1-min incubation and centrifugation at $14,000 \times g$ for $10 \mathrm{~min}$. The supernatant then was added to $600 \mu \mathrm{l}$ of binding matrix, incubated for $5 \mathrm{~min}$, and pulsed for $5 \mathrm{~s}$. The resultant pellet was resuspended gently in $500 \mu$ of SEWS-M wash solution and placed on a SPIN column (Qbiogene) for purification of genomic DNA. Bound DNA was eluted with 100 $\mu \mathrm{l}$ of DES and quantified via DNA gel electrophoresis as described above.

Primers used for multiplex PCR are listed in Table 2. Primers specific to the chitin synthase 1 gene, $C H S-1$ (11), were added as an internal control for the presence of fungal DNA. When used with primer TB71F, primer TB60R (43) amplifies both ToxB in race 5 and the ToxB-like sequence in race 3 , whereas primer TB58R (43) amplifies only toxb from race 4 . Reaction conditions were as follows: $1 \times$ Taq polymerase buffer, $200 \mu \mathrm{M}$ each dNTP, $200 \mathrm{nM}$ each primer, $2 \%$ (vol/vol) dimethyl sulfoxide, $1.25 \mathrm{U}$ of Taq polymerase, and $10 \mathrm{ng}$ of DNA template in $25 \mu \mathrm{l}$. Following an initial $1-\mathrm{min}, 94^{\circ} \mathrm{C}$ denaturation, samples underwent 30 cycles of $94^{\circ} \mathrm{C}$ for $45 \mathrm{~s}, 58^{\circ} \mathrm{C}$ for $30 \mathrm{~s}$, and $72^{\circ} \mathrm{C}$ for $1 \mathrm{~min}, 30 \mathrm{~s}$, ending with a final $7-\mathrm{min}$ extension at $72^{\circ} \mathrm{C}$. We repeated multiplex PCR on at least two independent DNA samples.

\section{RESULTS}

Phenotypic characterization. The standard set of five wheat differentials were inoculated with the $P$. tritici-repentis isolates SO3 and PT82 to determine their race designation and, thus, the likely complement of HSTs they produce (Fig. 1). The disease profiles obtained were compared first with inoculation results from known races in our collection, races 1 to 5 (Table 1). For races 6, 7, and 8 (see Materials and Methods), we relied on inoculation with races 2,3 , and 5 to generate disease phenotype standards on corresponding susceptible differentials. To date, these races have been shown to produce only one toxin each, Ptr ToxA, Ptr ToxC, or Ptr ToxB, respectively (Table 1). Disease phenotypes resulting from inoculation with these races were assumed to be representative for each respective toxin. Disease phenotype standards then were used to reconstruct disease profiles for races 6,7 , and 8 (Table 1) to compare with inoculation results for SO3 and PT82. For example, Figure 1B (left panel) shows a disease profile reconstruction for race 8 .

SO3 previously was shown to lack the ToxA gene (18). At that time, it was assumed that $\mathrm{SO} 3$ was nonpathogenic because of the absence of ToxA. In contrast, subsequent inoculations of SO3 on the standard wheat differential set have revealed that it produces a disease phenotype matching that of race 2 (necrotic lesions with chlorotic halos on Glenlea and Katepwa, and a resistant reaction on other tested differentials) (Fig. 1A). The disease phenotype of PT82 did not match any of the disease profiles for races 1 to 5 (data not shown). However, comparison with disease phenotype standards revealed that PT82 shares the Ptr ToxA necrosis phenotype on Glenlea and Katepwa with race 2, the Ptr ToxC chlorosis phenotype on $6 \mathrm{~B} 365$ with race 3 , and the Ptr ToxB chlorosis phenotype on Katepwa and 6B662 with race 5 (Fig. 1B). Although the chlorotic symptoms elicited by PT82 were less severe than those caused by the race 5 isolate DW7, we declared it to be a positive chlorotic reaction because (i) it was within the range of symptoms documented by Strelkov and colleagues (54) for low and high virulence race 5 isolates on 6B662; (ii) a survey of published literature on races 5 (44,52), 6 (54), 7, and 8 (39) revealed that the reaction of $6 \mathrm{~B} 662$ to $\mathrm{Ptr}$ ToxB varies depending on the isolate; and (iii) it was distinctly different than the resistant response observed on the wheat differential Auburn (Fig. 1B, right panel). That PT82 exhibited all three toxin phenotypes led us initially to designate it as race 8 , which is characterized by the production of Ptr ToxA, Ptr ToxB, and Ptr ToxC (Table 1).

Genotypic characterization. We utilized a molecular approach to evaluate the phenotypically determined race designations of SO3 as race 2 and PT82 as race 8. The availability of the ToxA $(10,18)$ and ToxB (44) genes and antibodies (41) to both toxins facilitated Southern and Western analyses, respectively. Because Ptr ToxC has not been completely characterized, tools for genotypic analysis are not available. Hybridization patterns in Southern analyses for races 1 to 5 were as expected. The ToxA probe hybridized to $S a c \mathrm{I}$-digested genomic DNA of races 1 and 2, but not to that of races 3,4 , or 5 , whereas the ToxB probe hybridized to HindIII-digested genomic DNA of races 3, 4, and 5, but not to that of races 1 or 2 (Fig. 2A). Comparable results were obtained for hybridization of either probe to EcoRV-digested genomic DNA (data not shown). As shown by Western analyses, all races that contained ToxA produced Ptr ToxA; however, not all races with ToxB produced Ptr ToxB (Fig. 2B). Although races 3 and 4 possess homologs of ToxB (Fig. 2A), they do not produce detectable amounts of Ptr ToxB (Fig. 2B), nor do they infect Ptr ToxB-sensitive wheat differentials (data not shown). As expected, the race 5 isolate produced $\mathrm{Ptr}$ ToxB (Fig. 2B). 
For both SO3 and PT82, molecular characterization contradicted phenotypic race classification. Although SO3 demonstrated a Ptr ToxA phenotype on Glenlea and Katepwa (Fig. 1A) and mimics a race 2 disease profile, it is known to lack the ToxA gene (18). Due to this discrepancy, we reconfirmed the absence of ToxA (Fig. 2A) and Ptr ToxA production (Fig. 2B), confirming, in turn, that $\mathrm{SO} 3$ clearly is not a race 2 isolate. Consistent with its designation as race 8 , PT82 possessed the ToxA gene (Fig. 2A) and produced Ptr ToxA (Fig. 2B); however, it lacked the ToxB gene (Fig. 2A) and Ptr ToxB production (Fig. 2B), despite causing chlorosis on Katepwa (Fig. 1B) and 6B662 (Fig. 1B and C). Thus, PT82 is not race 8.

Comparison of PT82 and race 1 on the Ptr ToxB-sensitive wheat line 6B662. Due to the lack of the ToxB gene and Ptr ToxB production by $\mathrm{PT} 82$, we investigated the possibility that the phenotype on 6B662 caused by this isolate resulted from the combined production of Ptr ToxA and Ptr ToxC. To do so, we inoculated 6B662 with a race 1 isolate, which produces both Ptr ToxA and Ptr ToxC, and compared the resultant phenotype with that caused by PT82 (Fig. 1C). In contrast to the chlorotic reaction caused by $\mathrm{PT} 82$ on $6 \mathrm{~B} 662$, race 1 isolate SD8 produced a typical resistant response, which is characterized by distinct, dark-brown lesions. The response of $6 \mathrm{~B} 662$ to race 1 (Fig. 1C, left panel) is similar to the response of this cultivar to race 2 (Fig. 1A, left panel). Thus, it appears that the response of 6B662 to PT82 inoculation is not due to the combined effect of Ptr ToxA and Ptr ToxC, and also that PT82 is not race 1.

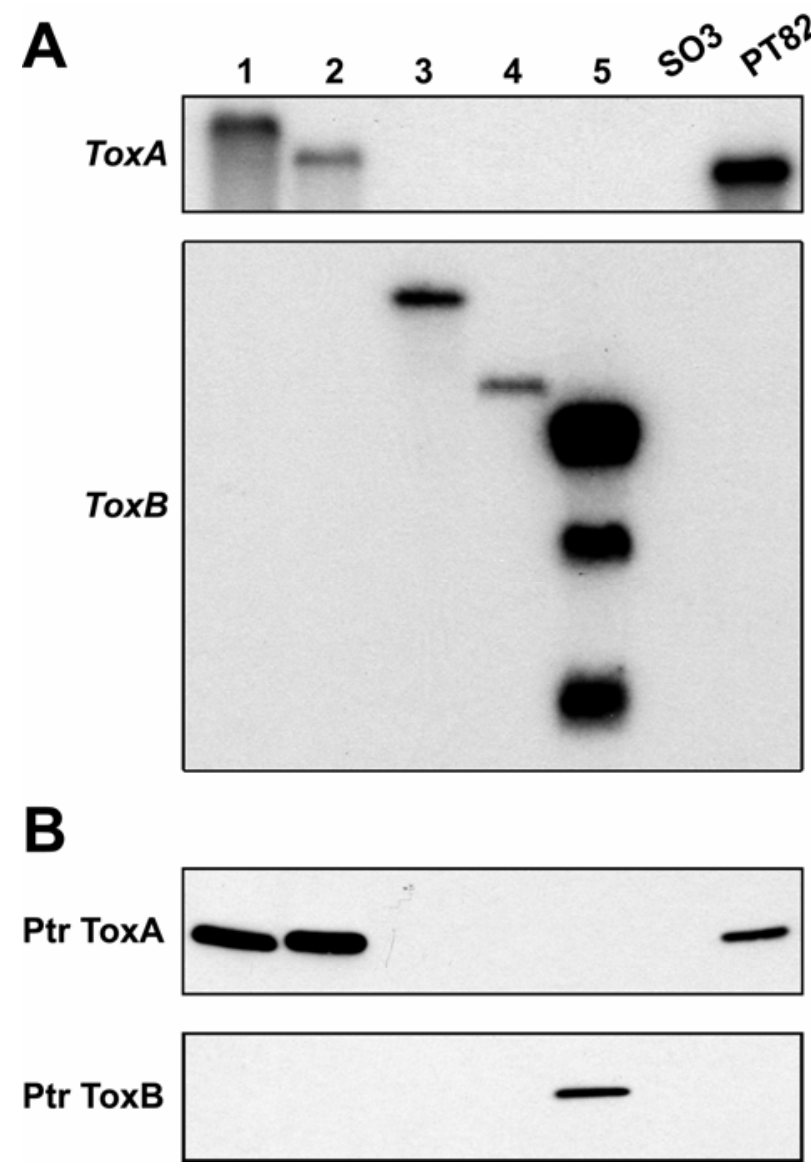

Fig. 2. Genetic characterization of PT82 and SO3 differs from phenotypically determined race designations. A, Southern analyses of PT82 and SO3 compared with Pyrenophora tritici-repentis races 1 to 5. SacI- or HindIIIdigested genomic DNA $(1 \mu \mathrm{g})$ from each isolate was hybridized with a ToxA or ToxB probe, respectively. B, Western analyses of PT82 and SO3 compared with $P$. tritici-repentis races 1 to 5. For each isolate, total precipitated protein from $500 \mu \mathrm{l}$ or $1 \mathrm{ml}$ of crude culture filtrate was subjected to Western analyses by using Ptr ToxA- or Ptr ToxB-specific antibodies, respectively.
Multiplex PCR. To facilitate rapid characterization of $P$. triticirepentis isolates, a PCR-based approach was developed to simultaneously identify disease determinants whose genes have been characterized. Primer sets were designed to amplify portions of both the ToxA and ToxB open reading frames (Table 2). The ToxA primer set amplified a 573-bp fragment, whereas the ToxB primer set amplified a 232-bp fragment (Fig. 3A). Primers (Table 2) for $C H S-1$ (11), the gene for chitin synthase, were included as an internal control for fungal DNA and produced a 275-bp amplification product (Fig. 3). These three amplification product sizes were easily distinguished by DNA agarose gel electrophoresis and, thus, proved useful for multiplex PCR.

Multiplex PCR amplification patterns for races 1 to 5 (Fig. 3A) were as expected based on results of Southern analyses (Fig. 2A). Races 1 and 2 yielded amplicons with ToxA-specific primers and races 3, 4, and 5 yielded amplicons with ToxB-specific primers (Fig. 3A). Two additional primer sets (Table 2) differentiated the ToxB sequences in races 3 and 5 from toxb, the ToxB homolog in race 4 isolate SD20 (Fig. 3B and $C$ ). When paired with the forward primer TB71F, reverse primer TB60R (43) was specific to the ToxB sequences in races 3 and 5 (Fig. 3B), whereas reverse primer TB58R was specific to toxb in race 4 (Fig. 3C). Multiplex PCR amplification patterns for SO3 and PT82 (Fig. 3A) also confirmed Southern analyses (Fig. 2A). SO3 tested negative for both genes, whereas PT82 tested positive for ToxA but not ToxB. A $C H S$ amplification product was detected in every PCR reaction that contained fungal DNA (Fig. 3).

\section{DISCUSSION}

P. tritici-repentis exhibits a complex race structure in its interaction with wheat (Table 1). Eight races are distinguished by the differential expression of the three currently identified HSTs produced by this fungus, which in turn often are identified by distinct disease reactions on current wheat differentials. Additional races of $P$. tritici-repentis have been suggested $(2,5,16$, $42,45)$ but await publication in a peer-reviewed journal. Although $P$. tritici-repentis race classification has been based primarily on disease phenotype, we present two examples where using disease phenotype alone to designate race and associated toxin production led to erroneous assignments. Inoculation of the $P$. tritici-repentis isolates SO3 and PT82 on the standard wheat differential set indicates classification as race 2 and 8 , respectively (Fig. 1). However, genetic characterization reveals that these isolates do

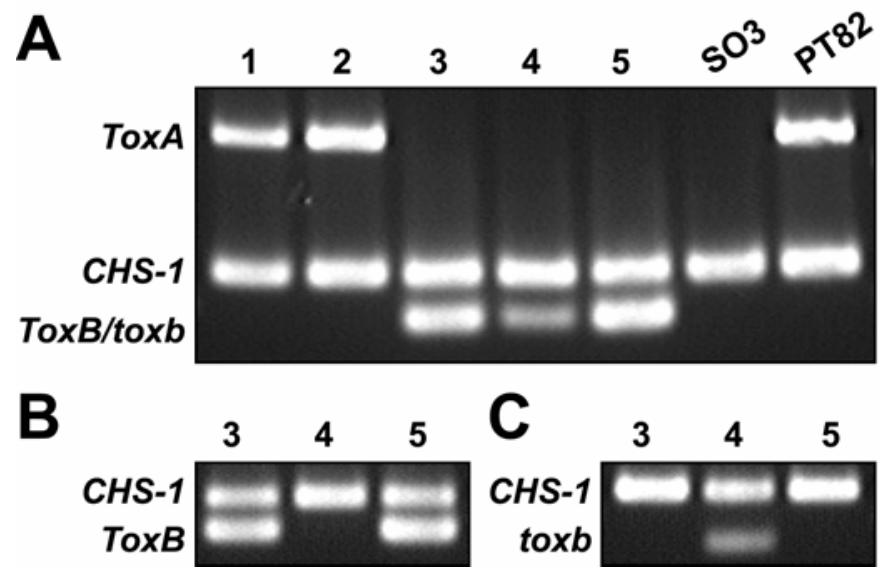

Fig. 3. Multiplex polymerase chain reaction (PCR) detection of host-selective toxin genes in isolates of Pyrenophora tritici-repentis. A, Agarose gel electrophoresis of multiplex PCR amplification products from genomic DNA of SO3, PT82, and races 1 to 5. B, Multiplex PCR modified to include ToxBspecific primers. C, Multiplex PCR modified to include tox $b$-specific primers. Primers for the chitin synthase 1 gene, $C H S$ - 1 , provide an internal control for the presence of fungal DNA. 
not possess all of the associated HSTs expected for these race assignments (Figs. 2 and 3); specifically, SO3 lacks the ToxA gene and Ptr ToxA production and PT82 lacks the ToxB gene and Ptr ToxB production. Because races of $P$. tritici-repentis are distinguished by the HSTs they produce (51), not just on disease phenotype alone, the fact that $\mathrm{SO} 3$ does not possess the ToxA gene and PT82 does not possess the ToxB gene is evidence enough that these isolates cannot be classified as race 2 or race 8 , respectively. Thus, to ensure accurate race classification, our results suggest that genotypic confirmation should accompany, where possible, phenotypic characterization when designating a $P$. tritici-repentis isolate to race.

Inclusion of genotypic characterization also has the potential to eliminate the subjectivity inherent in visual assessments of disease phenotype, as was the case for race classification in Cochliobolus carbonum, causal agent of Northern leaf spot and ear rot of maize (Zea mays L.). Exclusive of race 1, which is unequivocally identifiable by disease phenotype due to the production of the HST HC-toxin $(27,49,59)$, Jones and Dunkle (31) declared C. carbonum race identification based on disease reaction to be ambiguous, faulting both phenotypic variation among different isolate-cultivar combinations and the use of an inconsistent set of inbred lines for race characterization. As such, they examined whether fungal genotyping could be used to discern races of $C$. carbonum and found that PCR amplification with both arbitrary and gene-specific primers is useful for $C$. carbonum race differentiation. A similar potential for subjectivity in the $P$. tritici-repentis-wheat interaction is highlighted by the range of chlorotic symptoms observed on the wheat differential 6B662 in response to infection by various Ptr ToxB-producing isolates. Differences in chlorosis are observed both between isolates of the same race (i.e., low- and high-virulence race 5 isolates) and among isolates of different races (i.e., races 5, 6, 7, and 8) $(39,44,54)$. Because genotypic characterization provides an objective assessment of the presence of an HST and, thus, race identity, it promises to provide similar benefits to $P$. triticirepentis race classification as were obtained for $C$. carbonum.

Although the identification of previously unidentified phenotypegenotype combinations suggests that we have uncovered two new races of $P$. tritici-repentis that potentially produce two new toxic activities on wheat (for $\mathrm{SO} 3$, the necrotic disease reaction on Glenlea and Katepwa [Fig. 1A]; for PT82, the chlorotic disease reaction on Katepwa and 6B662 [Fig. 1B and C]), official race designation of these isolates awaits their thorough characterization. Thus, a priority in our laboratory is to characterize the putative races represented by $P$. tritici-repentis isolates SO3 and PT82 and their associated toxic activities, including the genetic determinants responsible for toxin production. Evidence suggests that the necrotic symptoms produced by SO3 on Glenlea and Katepwa are caused by a previously undescribed proteinacous HST (48), which we have tentatively named Ptr ToxD (42). It must be noted that an independently identified toxic compound also was simultaneously labeled as Ptr ToxD $(5,45)$, although official designation of either of these toxic activities as an HST awaits formal publication as designated by the criteria for standardized $P$. triticirepentis HST nomenclature (15). Similar standardization of criteria for $P$. tritici-repentis race designation has yet to be established; however, the tan spot research community is aware of this need and a collaborative publication similar to that for $P$. triticirepentis HST nomenclature (15) is anticipated.

A logical requirement for designation of a new race is the development of a positive screen for its identification. Ideally, race classification would be based on a standard set of differentials made up of distinct cultivars specific to each unique toxic compound produced by $P$. tritici-repentis. Indeed, identification of a cultivar specific for the toxic compound produced by $\mathrm{SO} 3$ is a current effort in our laboratory, although we have yet to identify a cultivar that separates sensitivity to Ptr ToxA from sensitivity to the toxic compound produced by SO3 (I. Pandelova, O. RieraLizarazu, and L. M. Ciuffetti, unpublished data). However, implementation of an expanded differential set for race classification in lieu of the inclusion of genotypic characterization deserves careful consideration. First, it appears that two putatively distinct toxic compounds (Ptr ToxA and the putative toxic compound produced by SO3) can cause similar symptoms on the same host genotype. Because this scenario may not be unique, the exclusion of genetic confirmation of phenotypic race characterization could lead to misclassifications similar to those presented here. Second, infinite expansion of the differential set to account for each newly characterized toxic compound eventually could make race classification based on phenotype too cumbersome for individual laboratory implementation (12). The ease with which genotypic characterization can be executed provides yet another reason why it should complement disease phenotype in the classification of $P$. tritici-repentis isolates to race.

Indeed, the versatility of PCR-based methodologies has led to their widespread application to investigations in plant pathology (29). Races of fungal pathogens most commonly are distinguished genotypically by molecular marker methods that employ arbitrary primers, such as restriction fragment length polymorphism $(1,32$, $40,60)$, random amplified polymorphic DNA $(8,13,19,26,28,33$, 60 ), and amplified fragment polymorphism (AFLP) assays (63), although some methods utilize specific primers $(30,61)$. Because AFLP analysis did not differentiate between the races of $P$. triticirepentis (24), we took advantage of the intimate association between HST production and race identity to develop a straightforward and high-throughput multiplex PCR assay based on HST gene-specific primers (Table 2) to aid in race differentiation (Fig. $3)$.

ToxA and ToxB currently are the only HST genes available for use in genetic screens of $P$. tritici-repentis. Due to the worldwide distribution of $P$. tritici-repentis races that possess the ToxA or ToxB genes $(3,6,22,35,36,38,51)$, our multiplex PCR approach promises to be very useful for characterization of isolates to race. Even so, genotypic race characterization alone cannot yet replace phenotypic race designation. Above all, disease determinants other than Ptr ToxA and Ptr ToxB have not been fully characterized. The most glaring omission from our multiplex PCR assay is a screen for the presence of Ptr ToxC. The gene or genes involved in the synthesis of Ptr ToxC, a disease determinant produced by the $P$. tritici-repentis races $1,3,6$, and 8 (Table 1), have yet to be cloned. Because race 1 isolates are prevalent throughout the world $(3,6,22,35,36,38,51)$ and race 3 isolates have been found in North America (22,51), Europe (6), and Asia $(38,51), \operatorname{Ptr}$ ToxC is the leading candidate for inclusion into the multiplex PCR approach.

The presence of ToxB homologs in races that are not pathogenic on Ptr ToxB-sensitive wheat, in particular in race 3 (50) and race $4(43,50)$, also confounds exclusive use of our multiplex PCR to designate race. Although nonpathogenic race 4 isolates can be identified with our toxb-specific primers (Fig. 3C), our ToxBspecific primers recognize both $T o x B$ in race 5 and its homolog in race 3 isolates (Fig. $3 \mathrm{~B}$ ). Because race 3 isolates do not produce Ptr ToxB (Fig. 2B), it follows that all positive multiplex PCR results obtained with our ToxB-specific primer set require direct isolation of the toxin from crude culture filtrate or confirmation of Ptr ToxB expression via Western analysis (Fig. 2B). Even so, multiplex PCR serves to limit the number of isolates that necessitate these more laborious manipulations. Alternatively, development of a race 3-specific primer set could alleviate this concern.

Our results reveal that a combination of phenotypic and genotypic characterization should be used for $P$. tritici-repentis race designation. Despite the production of characterized disease phenotypes by $P$. tritici-repentis isolates SO3 and PT82, genotypic characterization revealed the absence of the HSTs suggested by inoculation of the differential set. The identification of previously unidentified phenotype-genotype combinations suggests 
that these isolates represent two new races of $P$. tritici-repentis that potentially produce two new toxic compounds on wheat. However, these await thorough characterization. The likely discovery of new toxic compounds produced by $P$. tritici-repentis, both as suggested here on the current differential set and as predicted on an expanded differential set $(12,38)$, indicates an even more complex race structure for $P$. tritici-repentis than already described. Additionally, in a community effort that currently is in progress in our laboratory in collaboration with the Broad Institute (25), completion of the genomic sequence of a race 1 isolate and the production of EST libraries from additional races promise to significantly increase the discovery rate of pathogenicity or virulence factors produced by this fungus. The complexity of the interaction between $P$. tritici-repentis and wheat emphasizes the need for systematic characterization of the HSTs and races of $P$. tritici-repentis, and for the availability of all published races and differentials for accomplishing this goal. As our understanding of the $P$. tritici-repentis-wheat interaction becomes more defined, additional genotypic tools will become available to evaluate this system.

\section{ACKNOWLEDGMENTS}

This work was supported by the National Research Initiative of the United States Department of Agriculture Cooperative State Research Education and Extension Service, grant number 2003-35319-13476. We thank those who contributed isolates of $P$. tritici-repentis, including W. W. Bockus (Kansas State University, Manhattan) for PT82, G. Buchenau (South Dakota State University, Brookings) for SD8 and SD20, L. Lamari (University of Manitoba, Winnipeg, Canada) for 86-124 and D308, and the late L. Francl (Pennsylvania State University, University Park) and S. Ali (North Dakota State University, Fargo) for DW7; R. Tuori for primer TA4bF, J. P. Martinez for primer TB58R and the Ptr ToxB antibody, and J. Spatafora for use of his FastPrep Instrument; V. Manning for technical assistance and critical review; and T. Wolpert and K. Johnson for helpful suggestions and critical review.

\section{LITERATURE CITED}

1. Abdennadher, M., and Mills, D. 2000. Telomere-associated RFLPs and electrophoretic karyotyping reveal lineage relationships among racespecific strains of Ustilago hordei. Curr. Genet. 38:141-147.

2. Ali, S., and Francl, L. J. 2002. A new race of Pyrenophora tritici-repentis from Brazil. Plant Dis. 86:1050.

3. Ali, S., and Francl, L. J. 2003. Population race structure of Pyrenophora tritici-repentis prevalent on wheat and noncereal grasses in the Great Plains. Plant Dis. 87:418-422.

4. Ali, S., Francl, L. J., and De Wolf, E. D. 1999. First report of Pyrenophora tritici-repentis race 5 from North America. Plant Dis. 83:591

5. Ali, S., Ling, H., Meinhardt, S., and Francl, L. 2002. A new race of Pyrenophora tritici-repentis that produces a putative host-selective toxin. (Abstr.) Phytopathology 92:S3.

6. Ali, S., Sarova, J., and Wakulinsky, W. 2004. Pyrenophora tritici-repentis races in the Czech Republic and Poland. (Abstr.) Phytopathology 94:S3.

7. Andrie, R. M., Bockus, W. W., and Ciuffetti, L. M. 2003. Pyrenophora tritici-repentis race 8 identified in North America. (Abstr.) Phytopathology 93:S4.

8. Assigbetse, K. B., Fernandez, D., Dubois, M. P., and Geiger, J.-P. 1994. Differentiation of Fusarium oxysporum f. sp. vasinfectum races on cotton by random amplified polymorphic DNA (RAPD) analysis. Phytopathology 84:622-626.

9. Ballance, G. M., Lamari, L., and Bernier, C. C. 1989. Purification and characterization of a host-selective necrosis toxin from Pyrenophora tritici-repentis. Physiol. Mol. Plant Pathol. 35:203-213.

10. Ballance, G. M., Lamari, L., Kowatsch, R., and Bernier, C. C. 1996. Cloning, expression and occurrence of the gene encoding the Ptr necrosis toxin from Pyrenophora tritici-repentis. Mol. Plant Pathol. Online publication www.bspp.org.uk/mppol/] 1996/1209ballance.

11. Carbone, I., and Kohn, L. M. 1999. A method for designing primer sets for speciation studies in filamentous ascomycetes. Mycologia 91:553-556.

12. Caten, C. E. 1987. The concept of race in plant pathology. Pages 21-37 in: Populations of Plant Pathogens: Their Dynamics and Genetics. M. S. Wolfe and C. E. Caten, eds. Blackwell Scientific Publications, Oxford.
13. Chen, X., Line, R. F., and Leung, H. 1995. Virulence and polymorphic DNA relationships of Puccinia striiformis f. sp. hordei to other rusts. Phytopathology 85:1335-1342.

14. Church, G. M., and Gilbert, W. 1984. Genomic sequencing. Proc. Natl. Acad. Sci. USA 81:1991-1995.

15. Ciuffetti, L. M., Francl, L. J., Ballance, G. M., Bockus, W. W., Lamari, L., Meinhardt, S. W., and Rasmussen, J. B. 1998. Standardization of toxin nomenclature in the Pyrenophora tritici-repentis/wheat interaction. Can. J. Plant Pathol. 20:421-424.

16. Ciuffetti, L. M., Manning, V. A., Martinez, J. P., Pandelova, I., and Andrie, R. M. 2003. Proteinaceous toxins of Pyrenophora tritici-repentis and investigation of the site-of-action of Ptr ToxA. Pages 96-102 in: Proceedings of the Fourth International Wheat Tan Spot and Spot Blotch Workshop. J. B. Rasmussen, T. L. Friesen and S. Ali, eds. North Dakota Agricultural Experiment Station, Bemidji, MN.

17. Ciuffetti, L. M., and Tuori, R. P. 1999. Advances in the characterization of the Pyrenophora tritici-repentis-wheat interaction. Phytopathology 89:444-449.

18. Ciuffetti, L. M., Tuori, R. P., and Gaventa, J. M. 1997. A single gene encodes a selective toxin causal to the development of tan spot of wheat. Plant Cell 9:135-144.

19. Crowhurst, R. N., Hawthorne, B. T., Rikkerink, E. H. A., and Templeton, M. D. 1991. Differentiation of Fusarium solani f. sp. cucurbitae races 1 and 2 by random amplification of polymorphic DNA. Curr. Genet. 20:391-396.

20. De Wolf, E. D., Effertz, R. J., Ali, S., and Francl, L. 1998. Vistas of tan spot research. Can. J. Plant Pathol. 20:349-444.

21. Effertz, R. J., Meinhardt, S. W., Anderson, J. A., Jordahl, J. G., and Francl, L. J. 2002. Identification of a chlorosis-inducing toxin from Pyrenophora tritici-repentis and the chromosomal location of an insensitivity locus in wheat. Phytopathology 92:527-533.

22. Engle, J. S., Lipps, P. E., and Friesen, T. L. 2004. Distribution of tan spot and race structure of Pyrenophora tritici-repentis in Ohio. (Abstr.) Phytopathology 94:S28.

23. Fling, S. P., and Gregerson, D. S. 1986. Peptide and protein molecular weight determination by electrophoresis using a high-molarity tris buffer system without urea. Anal. Biochem. 155:83-88.

24. Friesen, T. L., Ali, S., Klein, K. K., and Rasmussen, J. B. 2005. Population genetic analysis of a global collection of Pyrenophora triticirepentis, causal agent of tan spot of wheat. Phytopathology 95:1144-1150.

25. Galagan, J. E., Henn, M. R., Ma, L.-J., Cuomo, C. A., and Birren, B. 2005. Genomics of the fungal kingdom: insights into eukaryotic biology. Genome Res. 15:1620-1631

26. Goodwin, P. H., and Annis, S. L. 1991. Rapid identification of genetic variation and pathotype of Leptosphaeria maculans by random amplified polymorphic DNA assay. Appl. Environ. Microbiol. 57:2482-2486.

27. Gross, M. L., McCrery, D., Crow, F., Tomer, K. B., Pope, M. R., Ciuffetti, L. M., Knoche, H. W., Daly, J. M., and Dunkle, L. D. 1982. The structure of the toxin from Helminthosporium carbonum. Tetrahedron Lett. 23:5381-5384

28. Guthrie, P. A. I., Magill, C. W., Frederiksen, R. A., and Odvody, G. N. 1992. Random amplified polymorphic DNA markers: a system for identifying and differentiating isolates of Colletotrichum graminicola. Phytopathology 82:832-835.

29. Henson, J. M., and French, R. 1993. The polymerase chain reaction and plant disease diagnosis. Annu. Rev. Phytopathol. 31:81-109.

30. Jiménez-Gasco, M. M., and Jiménez-Díaz, R. M. 2003. Development of a specific polymerase chain reaction-based assay for the identification of Fusarium oxysporum f. sp. ciceris and its pathogenic races 0, 1A, 5, and 6. Phytopathology 93:200-209.

31. Jones, M. J., and Dunkle, L. D. 1993. Analysis of Cochliobolus carbonum races by PCR amplification with arbitrary and gene-specific primers. Phytopathology 83:366-370.

32. Koch, E., Song, K., Osborn, T. C., and Williams, P. H. 1991. Relationship between pathogenicity and phylogeny based on restriction fragment length polymorphism in Leptosphaeria. Mol. Plant-Microbe Interact. 4:341-349.

33. Kolmer, J. A., Liu, J. Q., and Sies, M. 1995. Virulence and molecular polymorphism in Puccinia recondita f. sp. tritici in Canada. Phytopathology 85:276-285.

34. Lamari, L., and Bernier, C. C. 1989. Evaluation of wheat lines and cultivars to tan spot (Pyrenophora tritici-repentis) based on lesion type. Can. J. Plant Pathol. 11:49-56.

35. Lamari, L., and Bernier, C. C. 1989. Virulence of isolates of Pyrenophora tritici-repentis on 11 wheat cultivars and cytology of the differential host reactions. Can. J. Plant Pathol. 11:284-290.

36. Lamari, L., Gilbert, J., and Tekauz, A. 1998. Race differentiation in Pyrenophora tritici-repentis and survey of physiologic variation in western Canada. Can. J. Plant Pathol. 20:396-400.

37. Lamari, L., Sayoud, R., Boulif, M., and Bernier, C. C. 1995. Identification 
of a new race in Pyrenophora tritici-repentis: implications for the current pathotype classification system. Can. J. Plant Pathol. 17:312-318.

38. Lamari, L., Strelkov, S. E., Yahyaoui, A., Amedov, M., Saidov, M., Djunusova, M., and Koichibayev, M. 2005. Virulence of Pyrenophora tritici-repentis in the countries of the Silk Road. Can. J. Plant Pathol. 27:383-388.

39. Lamari, L., Strelkov, S., Yahyaoui, A., Orabi, J., and Smith, R. B. 2003. The identification of two new races of Pyrenophora tritici-repentis from the host center of diversity confirms a one-to-one relationship in tan spot of wheat. Phytopathology 93:391-396.

40. Levy, M., Correa-Victoria, F. J., Zeigler, R. S., Xu, S., and Hamer, J. E. 1993. Genetic diversity of the rice blast fungus in a disease nursery in Colombia. Phytopathology 83:1427-1433.

41. Manning, V. A., and Ciuffetti, L. M. 2005. Localization of Ptr ToxA produced by Pyrenophora tritici-repentis reveals protein import into wheat mesophyll cells. Plant Cell 17:3203-3212.

42. Manning, V. A., Pandelova, I., and Ciuffetti, L. M. 2002. A race for a novel host-selective toxin. (Abstr.) Phytopathology 92:S51.

43. Martinez, J. P., Oesch, N. W., and Ciuffetti, L. M. 2004. Characterization of the multiple-copy host-selective toxin gene, $\operatorname{ToxB}$, in pathogenic and nonpathogenic isolates of Pyrenophora tritici-repentis. Mol. PlantMicrobe Interact. 17:467-474.

44. Martinez, J. P., Ottum, S. A., Ali, S., Francl, L. J., and Ciuffetti, L. M. 2001. Characterization of the ToxB gene from Pyrenophora triticirepentis. Mol. Plant-Microbe Interact. 14:675-677.

45. Meinhardt, S., Ali, S., Ling, H., and Francl, L. 2003. A new race of Pyrenophora tritici-repentis that produces a putative host-selective toxin. Pages 117-121 in: Proceedings of the Fourth International Wheat Tan Spot and Spot Blotch Workshop. J. B. Rasmussen, T. L. Friesen and S. Ali, eds. North Dakota Agricultural Experiment Station, Bemidji, $\mathrm{MN}$.

46. Michaels, S. D., John, M. C., and Amasino, R. M. 1994. Removal of polysaccharides from plant DNA by ethanol precipitation. BioTechniques 17:274-276.

47. Orolaza, N. P., Lamari, L., and Ballance, G. M. 1995. Evidence of a hostspecific chlorosis toxin from Pyrenophora tritici-repentis, the causal agent of tan spot of wheat. Phytopathology 85:1282-1287.

48. Pandelova, I., and Ciuffetti, L. M. 2005. A proteomics-based approach for identification of the ToxD gene. Fungal Genet. Newsl. 52(Suppl.): 133.

49. Pope, M. R., Ciuffetti, L. M., Knoche, H. W., McCrery, D., Daly, J. M., and Dunkle, L. D. 1983. Structure of the host-specific toxin produced by Helminthosporium carbonum. Biochemistry 22:3502-3506.
50. Strelkov, S. E., Kowatsch, R. F., Ballance, G. M., and Lamari, L. 2006. Characterization of the ToxB gene from North African and Canadian isolates of Pyrenophora tritici-repentis. Physiol. Mol. Plant Pathol. 67:164-170

51. Strelkov, S. E., and Lamari, L. 2003. Host-parasite interactions in tan spot [Pyrenophora tritici-repentis] of wheat. Can. J. Plant. Pathol. 25:339-349.

52. Strelkov, S. E., Lamari, L., and Ballance, G. M. 1999. Characterization of a host-specific protein toxin (Ptr ToxB) from Pyrenophora tritici-repentis. Mol. Plant-Microbe Interact. 12:728-732.

53. Strelkov, S. E., Lamari, L., Ballance, G. M., and Orolaza, N. P. 1998 Isolation and mode of action of Ptr chlorosis toxin from Pyrenophora tritici-repentis. Pages 137-138 in: Molecular Genetics of Host-Specific Toxins in Plant Disease. K. Kohmoto and O. C. Yoder, eds. Kluwer Academic Publishers, Dordrecht, The Netherlands.

54. Strelkov, S. E., Lamari, L., Sayoud, R., and Smith, R. B. 2002. Comparative virulence of chlorosis-inducing races of Pyrenophora triticirepentis. Can. J. Plant Pathol. 24:29-35.

55. Tomas, A., and Bockus, W. W. 1987. Cultivar-specific toxicity of culture filtrates of Pyrenophora tritici-repentis. Phytopathology 77:1337-1340.

56. Tomas, A., Feng, G. H., Reeck, G. R., Bockus, W. W., and Leach, J. E. 1990. Purification of a cultivar-specific toxin from Pyrenophora tritici-repentis, causal agent of tan spot of wheat. Mol. Plant-Microbe Interact. 3:221-224.

57. Tuori, R. P., Wolpert, T. J., and Ciuffetti, L. M. 1995. Purification and immunological characterization of toxic components from cultures of Pyrenophora tritici-repentis. Mol. Plant-Microbe Interact. 8:41-48.

58. Tuori, R. P., Wolpert, T. J., and Ciuffetti, L. M. 2000. Heterologous expression of functional Ptr ToxA. Mol. Plant-Microbe Interact. 13:456-464.

59. Walton, J. D., Earle, E. D., and Gibson, B. W. 1982. Purification and structure of the host-specific toxin from Helminthosporium carbonum race 1. Biochem. Biophys. Res. Commun. 107:785-794.

60. Woo, S. L., Zoina, A., Del Sorbo, G., Lorito, M., Nanni, B., Scala, F., and Noviello, C. 1996. Characterization of Fusarium oxysporum f. sp. phaseoli by pathogenic races, VCGs, RFLPs, and RAPD. Phytopathology 86:966-973.

61. Xue, B., Goodwin, P. H., and Annis, S. L. 1992. Pathotype identification of Leptosphaeria maculans with PCR and oligonucleotide primers from ribosomal internal transcribed spacer sequences. Physiol. Mol. Plant Pathol. 41:179-188.

62. Zhang, H., Francl, L. J., Jordahl, J. G., and Meinhardt, S. W. 1997. Structural and physical properties of a necrosis-inducing toxin from Pyrenophora tritici-repentis. Phytopathology 87:154-160.

63. Zhong, S., and Steffenson, B. J. 2001. Virulence and molecular diversity in Cochliobolus sativus. Phytopathology 91:469-476 